\title{
Pengenalan Ecoliteracy pada Anak Usia Dini melalui Metode Bercerita
}

\author{
Masyunita Siregar ${ }^{1 凶}$ Sri Martini Meilani² ${ }^{\text {Agung Purwanto }}{ }^{3}$ \\ Pendidikan Anak Usia Dini, Universitas Negeri Jakarta \\ DOI: $10.31004 /$ obsesi.v5i1.700
}

\begin{abstract}
Abstrak
Permasalahan lingkungan yang disebabkan oleh tangan jahil manusia semakin banyak, khususnya permasalahan sampah. Hal ini didukung fakta yang disampaikan direktur pengelolaan sampah kementrian lingkungan hidup dan kehutanan bahwa $72 \%$ masyarakat Indonesia kurang peduli dengan masalah sampah dan komposisi sampah plastik terus mengalami peningkataan tepatnya tahun 2015 angka persentase kenaikan sampah plastik mencapai $11 \%$. Pemahaman untuk menjaga keseimbangan lingkungan alam (ecoliteracy) perlu diberikan sejak usia dini. Penelitian ini menggunakan pendekatan kualitatif dengan teknik studi literatur. Hasil penelitian menunjukkan bahwa salah satu cara pengenalan ecoliteracy pada anak usia dini adalah melalui metode bercerita. Studi literatur menunjukkan bahwa cerita adalah strategi yang dapat digunakan untuk mengenalkan ecoliteracy melalui alur cerita, pesan moral dan emosi dari cerita yang diceritakan kepada anak. Pemahaman ecoliteracy tidak hanya tentang kognitif tetapi juga tentang emosional, tindakan dan spirit dan hal tersebut dapat diberikan melalui metode bercerita.
\end{abstract}

Kata Kunci: ecoliteracy; metode bercerita; anak usia dini

\begin{abstract}
Environmental problems caused by human ignorant hands are increasing, especially the problem of garbage. This is supported by the fact conveyed by the director of waste management at the Ministry of Environment and Forestry that $72 \%$ of Indonesian people are less concerned with the problem of waste and the composition of plastic waste continues to experience an increase to be precise in 2015 the percentage increase in plastic waste reached $11 \%$. Understanding to maintain the balance of the natural environment (ecoliteracy) needs to be given from an early age. This study uses a qualitative approach with literature study techniques. The results showed that one way to introduce ecoliteracy in early childhood is through storytelling. Literature studies show that stories are a strategy that can be used to introduce ecoliteracy through storylines, moral messages and emotions from stories that are told to children. Understanding ecoliteracy is not only about cognitive but also about emotional, action and spirit and this can be provided through storytelling methods
\end{abstract}

Keywords: ecoliteracy; method of storytelling; early childhood

Copyright (c) 2020 Masyunita Siregar, Sri Martini Meilani, Agung Purwanto

$\triangle$ Corresponding author:

Email Address : masyunita14@gmail.com (Medan, Indonesia)

Received 27 July 2020, Accepted 7 August 2020, Published 11 August 2020 


\section{PENDAHULUAN}

Pendidikan lingkungan perlu diberikan kepada peserta didik, bahkan sejak usia dini, agar keseimbangan lingkungan hidup tetap terjaga kelestariannya. Hal ini sesuai dengan pernyataan Bowker bahwa komunitas ilmiah mengakui keaksaraan ilmiah seumur hidup dan rasa hormat terhadap alam didasarkan pada pembentukan nilai-nilai dan sikap yang dikembangkan dalam pembelajaran awal tahun, yaitu, antara usia tiga dan tujuh tahun (Slarp, 2014). Sikap peduli lingkungan yang ditanamkan sejak dini akan menjadi karakter anak hingga usia dewasa. Sehingga anak akan lebih peka dengan keadaan lingkungan sekitarnya termasuk lingkungan alam tempat tinggalnya. Serta permasalahan lingkungan akan dapat diatasi dan dicegah untuk masa yang akan datang.

Pemerintah Indonesia melalui progaram adiwiyata sudah menunjukkan kepedulian terhadap pendidikan lingkungan. Sejak tahun 2006-2019, sekolah adiwiyata telah memberikan kontribusi berupa pengurangan timbunan sampah dengan 3R (reduce, reuses, recycle ) sejumlahn 38.745 ton per tahun (Hadi, 2019). Kurikulum 2013 pendidikan anak usia dini juga memuat peduli lingkungan alam sebagai salah satu kompetensi dasar. Kompetensi dasar yang dimaksud adalah kompetensi dasar mengenal lingkungan alam (hewan, tanaman, cuaca, tanah, air, batubatuan, dll) dan menyajikan berbagai karya yang berhubungan dengan lingkungan alam (hewan, tanaman, cuaca, tanah, air, batu-batuan, dll).

Namun, saat ini permasalahan lingkungan banyak terjadi akibat ulah tangan jahil manusia seperti penggundulan hutan tanpa melestraikannya, banjir karena buang sampah sembarangan, bahkan dampak buruk dari limbah rumah tangga dapat merusak ekosistem lingkungan. Permasalahan lingkungan hidup tersebut menggambarkan kurangnya kesadaran manusia untuk menjaga kelestarian lingkungan. Hal ini didukung fakta yang disampaikan direktur pengelolaan sampah kementrian lingkungan hidup dan kehutanan bahwa $72 \%$ masyarakat Indonesia kurang peduli dengan masalah sampah dan komposisi sampah plastik terus mengalami peningkataan tepatnya tahun 2015 angka persentase kenaikan sampah plastik mencapai $11 \%$ dan kementrian lingkungan hidup dan kehutanan memprediksi 10 tahun yang akan datang angka tersebut akan terus meningkat mencapai angka $16 \%$ (Badan Pusat Statistik, 2018). Sehingga pemahaman untuk menjaga keseimbangan lingkungan alam (ecoliteracy) perlu diberikan kepada setiap individu sejak dini.

Keraf mendefenisikan ecoliteracy sebagai istilah yang digunakan untuk menggambarkan manusia yang telah memiliki kesadaran tinggi akan pentingnya lingkungan hidup (Desfandi et al., 2017). Hal tersebut didukung oleh pernyataan Meena dan Alison (Jiwa \& Esa, 2014) yang menyatakan bahwa ecoliteracy tidak hanya membahas tentang konsep ekologi, tetapi juga tentang ekosistem tempat tinggal siswa. Untuk menjaga kelestarian lingkungan hidup yang lebih luas, kita perlu memulai dari hal paling dekat dengan lingkungan sekitar kita. Berdasarkan penjelasan defenisi ecoliteracy di atas, dapat disintesakan bahwa ecoliteracy adalah suatu kemampuan memahami lingkungan sekitar serta memahami cara untuk menjaga kelestarian lingkungan hidup disekiatar individu. Memberikan pemahaman tentang ecoliteracy kepada anak sejak dini dapat menjadikan anak sebagai individu yang memiliki kesadaran tinggi akan pentingnya menjaga kelestarian lingkungan sekitarnya. Selain itu peduli lingkungan juga merupakan salah satu karakter yang perlu dibekali kepada generasi Indonesia.

Pengenalan ecoliteracy pada anak usia dini dapat dilakukan melalui pembelajaran di sekolah. Mirza Desfandia, Enok Maryani, Dismand melakukan penelitian survey dengan judul Building Ecoliteracy Through Adiwiyata Program (Study at Adiwiyata School in Banda Aceh) dan hasil penelitian menujukkan bahwa kebijakan sekolah, implementasi kurikulum, budaya sekolah dan pengelolaan prasarana sekolah memiliki pengaruh positif terhadap ecoliteracy siswa (Mirza et al., 2017). Tentunya pembelajaran di kelas menjadi salah satu pengenalan ecoliteracy pada anak. Hasi penelitian Suci dan Nikawanti menunjukkan bahwa 
pengenalan ecoliteracy pada anak usia dini salah satunya melalui cerita (Putri \& Nikawanti, 2018). Hal senada juga dikemukakan oleh Yannis dan Gillian bahwa bercerita adalah strategi yang efektif dalam mencapai tujuan pendidikann untuk meningkatkan kesadarang lingkungan anak usia dini (Yannis \& Gillian, 2017). Berdasarkan latar belakang tersebut, peneliti akan menyajikan telaah literatur tentang pengenalan ecoliteracy melalui metode bercerita.

\section{METODOLOGI}

Penelitian ini merupakan penelitian dengan metode studi literatur dengan menelaah lebih dari 20 literatur terkait ecoliteracy dan metode bercerita. Teknik pengumpulan data yang dilakukan adalah dokumentasi, yaitu dokumen berupa literatur yang terkait dengan topik penelitian seperti artikel. Analisis data dalam penelitian ini merupakan analisis konten dan menggunakan teknik analisis data miles and hubermen yaitu reduksi data, penyajian data dan verifikasi data (Hamzah, 2020). Hasil dari berbagai telaah literatur ini akan digunakan untuk mengidentifikasi pengenalan ecoliteracy melalui metode bercerita pada anak usia dini. Tahapan penelitian yang dilakukan mengadopsi langkah-langkah penelitian kepustakaan dari M. Zed (Zed, 2008) sebagai berikut:

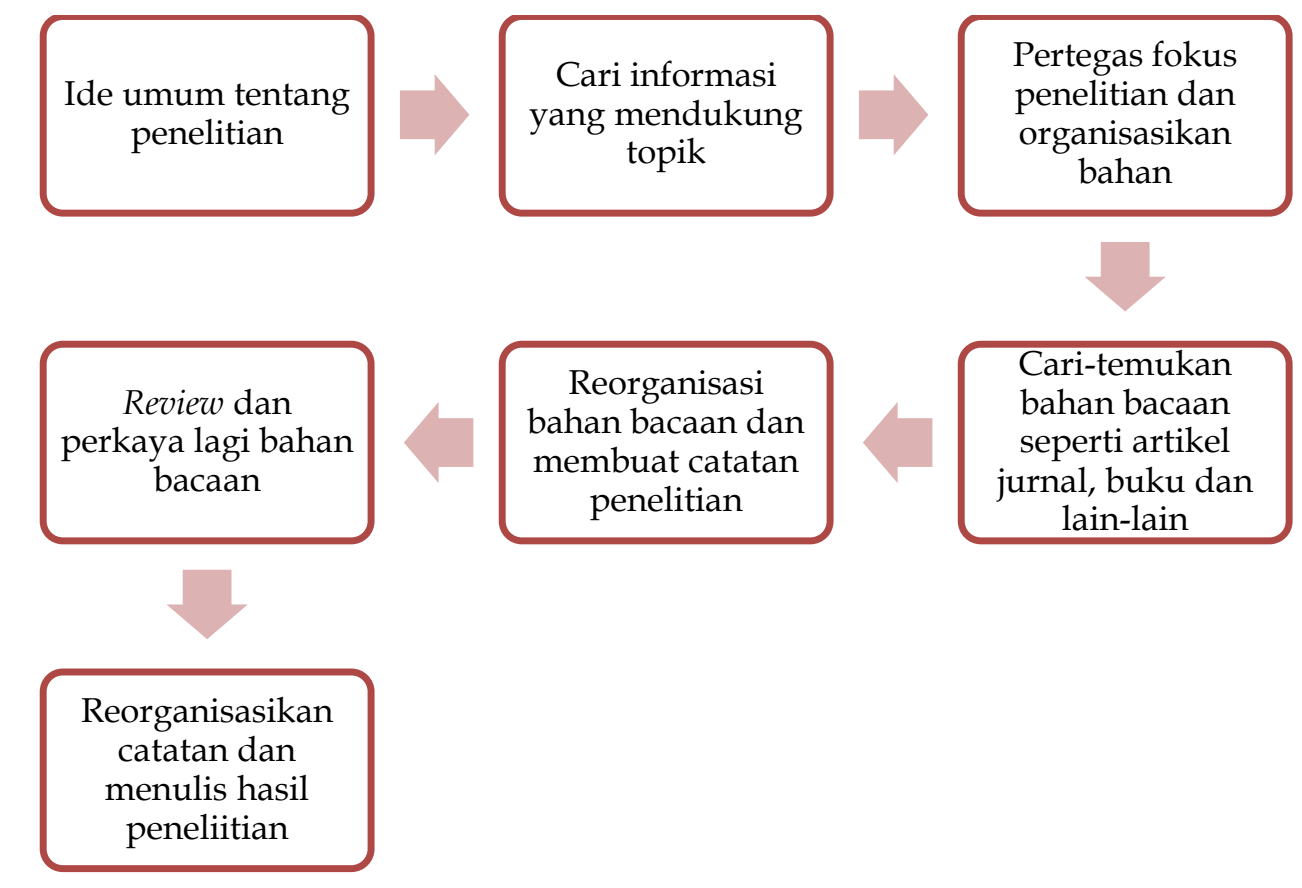

Bagan 1 Langkah-langkah penelitian kepustakaan

\section{HASIL DAN PEMBAHASAN \\ Ecoliteracy}

Istilah ecoliteracy pertama kali dipopularken oleh Capra dalam bukunya yang berjudul The web life tahun 1997 yang mengemukakan bahwa prinsip-prinsip ekologi berlaku untuk semua sistem kehidupan (Muthukrishnan, 2019). Ekosistem menghubungkan seluruh unsur yang ada didalamnya baik lingkungan hidup maupun tidak (Capra, 2010). Defenisi ecoliteracy adalah kemampuan "membaca" lingkungan dan "bertindak" dengan tujuan berkelanjutan dengan semua kebutuhan kita (Muthukrishnan, 2019). Nadiroh et al mendefenisikan ecoliteracy adalah pemahaman dan perilaku atau tindakan seseorang terhadap lingkungan (Nadiroh et al., 2019). Menurut Rabiatul dan Norizan ecoliteracy adalah kemampuan untuk memahami sistem alami yang terkait dengan kehidupan kita, termasuk pertimbangan konsekuensi dari tindakan manusia (Jiwa \& Esa, 2014). Sehingga dapat 
dideskripsikan bahwa ecoliteracy adalah pemahaman dan perilaku tentang lingkungan hidup yang berhubungan dengan sistem kehidupan dalam ekosistem, termasuk dampak yang ditimbulkan dari tindakan manusia.

Istilah lain ecoliteracy adalah kecerdasan ekologis. Kecerdasan adalah kapasitas untuk belajar dari pengalaman dan cara efektif berhadapan dengan lingkungan, sedangkan ekologis adalah pemahaman terhadap organisme dan ekosistemnya (Goleman, 2010). Kostelnik et al mengemukakan istilah kesadaran lingkungan yaitu keterhubungan kompleks di antara semua makhluk hidup dan lingkungan mereka (Kostelnik et al., 2017). Hal senada juga dikemukakan oleh Pitman dan Daniels bahwa ecoliteracy mencoba memperkenalkan dan memperbarui pemahaman orang tentang pentingnya kesadaran ekologi global, untuk menciptakan keseimbangan antara kebutuhan manusia dan kapasitas bumi untuk mempertahankannya (Pitman \& Daniels, 2016). Selain itu Dasrita juga mendefenisikan kesadaran lingkungan sebagai pengetahuan yang menggugah jiwa untuk melakukan tindakan yang dapat mendukung terciptanya kelestarian lingkungan hidup (Dasrita, 2018).

Berdasarkan penjelasan di atas, dapat ditarik suatu kesimpulan bahwa ecoliteracy adalah kemampuan memahami lingkungan sekitar untuk menjaga keseimbangan ekosistem alam dan akan berdampak pada kehidupan lebih lanjut di lingkungan ekosistem tersebut. Kemampuan memahami lingkungan dapat dilihat dari kepekaan terhadap lingkungan. Seperti menyadari tindakan membuang sampah sembarangan dapat menyebabkan banjir. Kebiasaan menggunakan kantong plastik, sedotan plastik dan membuang limbahnya sembarangan dapat merugikan mahluk hidup lainnya. Sehingga melek atau sadar lingkungan dapat diawali dengan memberikan pemahaman pentingnya menjaga kelestarian lingkungan dan dampaknya serta melakukan tindakan yang mampu melindungi kelestarian lingkungan.

Ada empat pakar yang mengemukakan framework ecoliteracy yaitu Orr, Capra (Center for Ecoliteracy), Cutter-Mackenzie and Smith, dan Wooltorton (McBride et al., 2013). Pertama adalah framework Orr yang dikemukakan pada tahun 1992 yaitu dengan isitilah dasar keaksaraan ekologis: pengetahuan, kepedulian, dan kompetensi praktis. Pemahaman yang luas tentang bagaimana orang dan masyarakat saling berhubungan satu sama lain dan sistem alami, dan bagaimana melakukannya secara berkelanjutan. Selanjutnya farmeworks menurut Capra dalam center for ecoliteracy yang dipakai tahun 1997/2002 / 2013 . Ada empat set kompetensi untuk ekoliterasi: (1) Kepala / kognitif - pendekatan dari perspektif sistem, memahami prinsip-prinsip ekologis mendasar (jaringan, sistem bersarang, siklus, aliran, pengembangan, keseimbangan dinamis), menilai dampak, dan efek etis dari tindakan manusia, membayangkan konsekuensi jangka panjang dari keputusan; (2) Hati / emosional - rasakan kepedulian, empati, dan rasa hormat terhadap orang lain dan makhluk hidup, menghargai berbagai perspektif, berkomitmen pada kesetaraan dan keadilan bagi semua orang; (3) Tangan / aktif - membuat dan menggunakan alat dan prosedur yang dibutuhkan oleh masyarakat yang berkelanjutan, mengubah keyakinan menjadi tindakan praktis dan efektif, menilai dan menyesuaikan penggunaan energi dan sumber daya; (4) Roh / koneksi mengalami keajaiban dan kekaguman terhadap alam, merasakan penghormatan terhadap Bumi dan semua makhluk hidup, merasakan ikatan yang kuat dengan dan penghargaan yang mendalam.

Ketiga adalah menurut Cutter-Mackenzie dan Smith pada tahun 2003, ada empat tingkat ecoliteracy: (1) sedikit pemahaman dan banyak kesalahpahaman tentang masalah lingkungan; (2) ekoliterasi nominal - pengakuan dan penggunaan beberapa istilah dasar yang digunakan dalam berkomunikasi tentang lingkungan, mulai mengidentifikasi masalah lingkungan dan masalah seputar solusi yang diusulkan; (3) ekoliterasi fungsional / operasional - pemahaman tentang organisasi dan fungsi sistem lingkungan dan interaksi dengan sistem manusia, pengetahuan dan keterampilan; (4) ekoliterasi yang sangat berkembang - pemahaman menyeluruh tentang bagaimana orang dan masyarakat saling berhubungan satu sama lain dan sistem alam, dan bagaimana melakukannya secara 
berkelanjutan, pemahaman menyeluruh tentang krisis lingkungan, pemahaman model keberlanjutan, mampu mensintesis informasi lingkungan dan bertindak dalam cara yang mengarah pada kelestarian lingkungan.

Terakhir tahun 2006 Wooltorton mengemukakan enam elemen ecoliteracy: (1) diri yang ekologis - rasa keterkaitan dengan siklus kehidupan berdasarkan perawatan dan kasih sayang, perluasan jiwa dan penghormatan terhadap orang lain atas dasar penghargaan terhadap perbedaan; (2) rasa tempat dan kewarganegaraan aktif - keterlibatan dalam budaya lokal, sejarah, dan komunitas organik bersama dengan ekosistem; (3) sistem berpikir dan hubungan - rasa relasionalitas, keterhubungan, dan konteks; (4) paradigma ekologi studi tentang keseluruhan, hubungan, dan jaringan, fokus pada pengetahuan kontekstual, pertimbangan kualitas, perhatian pada proses, studi pola; (5) pedagogi pendidikan untuk keberlanjutan - pendekatan eksperiensial, partisipatif dan multidisiplin, yang berfokus pada proses pembelajaran; (6) membaca dunia alam dan budaya - keterlibatan dengan alam sedini mungkin dengan ekoliterasi sebagai literasi pertama. Pemahaman ecoliteracy untuk anak usia dini mengikuti framework dari Capra tahun 2013 dalam center for ecoliteracy yaitu memahami prinsip-prinsip ekologi dasar dan menilai dampak dari tindakan manusia terhadap lingkungan, memiliki rasa empati, dan rasa hormat terhadap orang lain dan makhluk hidup, dapat menilai dan menyesuaikan penggunaan energi dan sumber daya dan terakhir rasa kekaguman terhadap alam.

Penelitian lain terkait ecoliteracy juga telah dilakukan beberapa peneliti, namun hanya beberapa penelitian yang fokus pada anak usia dini. Eun Jeong Ju and Jae Geun Kim (Ju \& Kim, 2011) yang melakukan penelitian research and development meneliti tentang tanaman dan lingkungan dan hasil penelitiannya menunjukkan adanya perubahan sikap psositif siswa terhadap lingkungan. Selanjutnya penelitian Deniz Saribas, Gaye Teksoz , Hamide Ertepinar (Saribas et al., 2014) yang berjudul The relationship between environmental literacy and self-efficacy beliefs toward environmental education dan hasil penelitiannya menemukan korelasi yang signifikan antara keyakinan self-efficacy mereka dan kepedulian mereka terhadap lingkungan. Salah satu penelitian yang paling relevan dengan penelitian ini adalah penelitian yang dilakukan Melissa Slarp (Slarp, 2014) yaitu penelitian dengan judul How ecoliterate is a five year old? Investigating the effects of a teaching intervention on kindergarten understanding of ecological concepts. dan hasilnya ekoliterasi mereka meningkat secara signifikan setelah intervensi, dan bahwa mereka mampu mempertahankan pengetahuan yang baru diperoleh. Berikutnya adalah penelitian Kelly Johnson dengan pendekatan studi literatur juga dengan judul Creative Connecting: Early Childhood Nature Journaling Sparks Wonder and Develops Ecological Literacy. Penelitian kualitatif tentang ecoliteracy pada siswa SMP oleh Rabiatul Adawiah Megat Jiwa, Norizan Esa (Jiwa \& Esa, 2014) menujukkan bahwa literasi ekologis siswa terbatas dan mereka tidak dapat menghubungkan apa yang mereka pelajari di kelas dengan lingkungan mereka. Sehingga ini menjadi pendukung pentingnya mengenalkan ecoliteracy sejak dini sehingga anak lebih cinta dan peka terhadap lingkungannya.

Penelitian studi literatur tentang pentingnya menanamkan ecoliteracy pada anak usia dini juga dilakukan oleh Mirza Desfandia, Enok Maryani , Dismand (Mirza et al., 2017) , namun yang menjadi perbedaan dengan studi literatur ini adalah penggunaan metode bercerita sebagai pengenalan ecoliteracy pada anak usia dini. Selain penelitian studi literatur, Mirza Desfandia, Enok Maryani , Dismand juga melakukan penelitian survey dengan judul Building Ecoliteracy Through Adiwiyata Program (Study at Adiwiyata School in Banda Aceh) (Desfandi et al., 2017)dan hasil penelitian menujukkan bahwa terdapat pengaruh yang positif dan signifikan kebijakan sekolah, implementasi kurikulum, budaya sekolah dan pengelolaan prasarana sekolah terhadap ecoliteracy siswa. Dhea Adela, Sukarno, Mintasih Indriayu (Adela et al., 2018) juga melakukan penelitian dengan studi kasus terhadap sekolah Adiwiyata dan hasil penelitian menunjukkan bahwa lingkungan pendidikan telah dilaksanakan melalui program intracurricular terintegrasi dalam pembelajaran kegiatan dan 
juga melalui program ekstrakurikuler. Guru dan siswa telah menerapkan sikap peduli lingkungan secara proaktif berdasarkan kurikulum berbasis Adiwiyata dan dalam upaya untuk mendorong ekoliterasi siswa. Namun demikian Penghargaan Adiwiyata lebih menonjol secara artifisial dalam simbol fisik ramah lingkungan jika dibandingkan dengan pembentukan budaya ramah lingkungan secara konsisten di seluruh komunitas sekolah. Terakhir adalah penelitian Heather D. Wallace Transdisciplinary learning in a kitchen garden: connecting to nature and constructing a path to ecoliteracy? dan temuan menunjukkan bahwa kunjungan yang sering dilakukan oleh anak-anak ke taman membangun keakraban dan meningkatkan empati dengan makhluk hidup, dan membangun minat dalam lingkungan alam.

\section{Metode Bercerita}

Metode bercerita adalah salah satu metode pembelajaran yang dapat diterapkan dalam pembelajaran anak usia dini. Penerapan metode bercrita pada anak usia dini dapat diberikan secara lisan dan juga dengan bantuan media yang mendukung visualisasi karakter dalam cerita. Bercerita merupakan upaya mengkomunikasikan kejadian dengan improvisasi kata (prosa atau puisi), gambar dan suara agar lebih semarak (Haigh \& Hardy, 2011). Moeslichatoen mengemukakan bahwa metode bercerita merupakan salah satu pemberian pengalaman belajar bagi anak TK dengan membawakan cerita kepada anak secara lisan (Moeslichatoen, 2004). Sedangkan menurut Chodijah metode bercerita adalah metode yang dapat meberikan pengalaman kepada anak dengan cara bertutur kata secara lisan (Chodijah, 2018). Para pelopor teori perkembangan moral dan pendidikan moral anak-anak jugamendukung penggunaan metode bercerita untuk menyampaikan pengetahuan tentang nilai-nilai moral kepada anak-anak (Nair et al., 2014).

Bercerita adalah salah satu metode yang digunakan untuk memperkuat ingatan dan proses bercerita memfasilitasi perubahan kognitif (Sarica \& Usluel, 2016). Hal senada juga dikemukakan oleh Masnipal bahwa bercerita dapat mengembangkan banyak aspek perkembangan seperti bahasa dan kognitif, nilai agama moral dan sosial emosioanal (Masnipal, 2018). Mallan menyatakan bercerita membantu mengembangkan imajinasi yang pada akhirnya membangun kompetensi pemecahan masalah. Oleh karena itu, mengembangkan imajinasi dapat memberdayakan siswa untuk mempertimbangkan ide-ide baru dan inventif (Mokhtar et al., 2011). Sedangkan menurut Asta dan Polly bercerita adalah dasar pengembangankosa kata dan literasi bagi anak usia dini (Cekaite \& Björk-Willén, 2018).

Berdasarkan beberapa defenisi di atas dapat ditarik kesimpulan metode bercerita adalah salah satu metode yang menggunakan unsur seni dalam penyampaiannya karena disertai dengan intonasi suara saat menyampaikan cerita dan juga dapat menggunakan media yang menarik untuk menyampaikan cerita kepada peserta didik. Bercerita adalah bentuk komunikasi secara lisan maupun dengan bahsa tubuh yang digunakan untuk mensugesti audiens untuk menerapkan pesan moral dalam cerita. Serta mengembangkan imajainasi yang dapat berpengaruh pada kemampuan pemecahan masalah. Melalui kegiatan bercerita dapat membantu berbagai aspek perkembangan dalam diri anak seperti pengebangan kosa kata, literasi, perkembangan intelektual, sosial emosional dan penanaman karakter dan moral pada anak sesuai dengan isi cerita.

Tujuan metode bercerita dalam pembelajaran anak usia dini adalah untuk mengembangkan aspek dalam diri anak seperti kemampuan intelektual, kemampuan berbahasa, mengenal emosi dan penenanaman nilai positif dalam diri anak. Hal serupa juga dikemukakan dalam hasil penelitian Isbell, Sobol, Lindauer, and Lowrance bahwa anak usia 3-5 tahun yang diberikan perlakuan dengan kegiatan bercerita lebih mampu memahami latar cerita, memahami pesan moral dan karakter dari cerita (Kalantari \& Hashemian, 2015). Menurut Zevenbergen dan whitehurst cerita adalah bahan mendengarkan yang efektif dan 
bermanfaat bagi anak-anak untuk mengembangkan literasi dan kemampuan menyimak bahasa pertama ataupun bahasa kedua (Oduolowu \& Oluwakemi, 2014).

Teknik bercerita dibedakan menjadi dua yaitu bercerita tanpa alat peraga dan bercerita dengan alat peraga. Pertama adalah bercerita tanpa alat peraga, adalah bentuk bercerita yang paling sering dilakukan dan guru harus memeperhatikan ekspresi wajah, gerak dan suara guru harus menstimulus imajinasi anak sesuai dengan isi cerita. Sedangkan bercerita dengan alat peraga adalah bentuk cerita yang menggunakan alat peraga yang membantu visualisasi sesuai isi cerita yang didengar anak (Chodijah, 2018).

Penggunaan metode bercerita dalam pembelajaran anak usia dini juga harus memperhatikan hal-hal seperti isi cerita harus terkait dengan dunia kehidupan anak usia dini, kegiatan bercerita dapat memberikan perasaan gembira, lucu dan mengasyikkan dan memberikan pengalaman yang baik bagi anak usia dini (Chodijah, 2018). Hal serupa juga dikemukakan oleh Yannis dan Gillian bahwa penting bagi guru untuk memperhatikan gagasan cerita dan keterkaitannya dengan kehidupan harus ekspilit dalam alur cerita (Yannis \& Gillian, 2017). Bercerita dengan alat peraga dibagi lagi menjadi dua kelompok yaitu bercerita dengan alat peraga langsung dan bercerita dengan alat peraga tidak langsung. Melalui media yang digunakan dalam menyampaikan cerita pada anak akan memudahkan menyampaikan isi cerita pada anak, termasuk dalam pengenalan ecoliteracy. Penyampaian cerita secara interaktif yaitu dengan adanya dialog dan mengajak anak berinteraksi selama proses penyampaian cerita memudahkan anak memahami isi pesan dari cerita. Selain itu, memadukan metode bercerita dengan percobaan sederhana sesuai dengan aktivitas dalam cerita merupakan cara untuk memperkenalkan ecoliteracy pada anak melalui metode cerita.

\section{Pengenalan Ecoliteracy pada Anak Usia Dini melalui Metode Bercerita}

Hasil studi literatur tentang ecoliteracy dan metode bercerita di atas memberikan gambaran bahwa ecoliteracy dapat diperkenalkan kepada anak usia dini melalui metode bercerita. Kaitan anatara kedua topik atau variabel penelitian tersebut terlihat dari beberapa hasil penelitian. Hasil penelitian Yannis dan Gillian menemukan bahwa bercerita adalah strategi yang efektif dalam mencapai tujuan pendidikann untuk meningkatkan kesadaran lingkungan anak usia dini (Yannis \& Gillian, 2017). Hal senada dikemukakan oleh Cekaite \& Björk-Willén, (Cekaite \& Björk-Willén, 2018) bahwa bercerita merupakan salah satu cara mempromosikan literasi pada anak usia dini, tentutnya termasuk literasi ekologi. Kegiatan bercerita secara interaksional antara anak dengan orang dewasa akan mempengaruhi kognisi sosial anak dan menjadi terintegrasi dengan hubungan sosial dan dapat diterima dalam komunitas sosial. Selain itu hasil penelitian Yulianti et al menunjukkan bahwa melalui buku cerita bermutan sains berwawasan konservasi dapat meningkatkan kepeduilan anak terhadap lingkungan. Hal ini terlihat dari perubahan pencapaian pada indikator membuang sampah di tempatnya yang mengalami peningkatan dari 35,95\% menjadi 92,19\% (Yulianti et al., 2014).

Penelitian tersebut membuktikan bahwa melalui cerita, ecoliteracy atau kesadaran lingkungan dapat dikenalkan pada anak usa dini. Menurut Dewi, Tirtayani, \& Ganing (Dewi et al., 2019) metode bercerita dapat menanamkan sikap budi pekerti pada anak melalui tokohtokoh yang ada dalam cerita, dapat mengembangkan keterampilan berbicara, membaca, menulis, dan menyimak, dapat mengembangkan kemampuan berempati, dapat menggetarkan perasaan anak, serta banyak mendapatkan pengalaman yang unik dan menarik.Hal senada juga dikemukakan oleh Setiawati et al (Yulianti et al., 2014) bahwa salah satu jalan memasuki dunia anak adalah melalui cerita sehingga terjadi keterlibatan pemahaman, mental, dan emosi antara yang bercerita dengan penerima cerita. Komponen yang dimanfaatkan untuk mengenalkan ecoliteracy pada anak adalah alur cerita, ponokohan serta berbagai emosi yang tertuang dalam cerita. Imajinasi anak dan pemahaman anak akan terstimulus dengan cerita yang disamapaikan oleh guru atau pendongeng. Empati anak terhadap permasalahan 
lingkungan yang disampaikan dalam cerita akan terbangun melalui emosi dari setiap penokohan. Melalui alur cerita yang disampaikan akan menstimulus emosi anak terhadap masalah lingkungan alam sekitarnya serta menambah wawasan pengetahuan anak tentang hubungan yang terjadi di alam sekitar. Pemahaman anak tentang pentingnya menjaga lingkungan juga terbagung dari pesan-pesan moral dari setiap cerita serta kemampuan anak dalam berpikir tentang sebab akibat dari suatu peristiwa atau permasalahan lingkungan yang terjadi.

\section{SIMPULAN}

Pemahaman ecoliteracy perlu diberikan kepada anak sejak dini. Memberikan pemahaman ecoliteracy sejak dini kepada anak menjadi salah satu solusi untuk menangani kerusakan lingkungan yang diciptakan manusia. Pemahaman ecoliteracy pada anak harus diberikan sesuai dengan prinsip belajar anak menyenangkan dan penuh dengan imajinasi. Salah satu cara pengenalan awal ecoliteracy kepada anak usia dini dapat diberikan melalui pembelajaran di sekolah dengan menerapkan metode bercerita. Bercerita merupakan startegi efektif untuk mengenalkan ecoliteracy pada anak, karena cerita adalah metode efektif untuk meningkatkan kesadaran anak tentang hubungan sosial. Artinya metode bercerita dapat meningkatkan nilai peduli lingkungan alam sekitar.

\section{UCAPAN TERIMA KASIH}

Terima kasih kepada Allah SWT yang telah memberikan kesehatan dan kesempatan sehingga penulis dapat menyelesaikan artikel ini. Kepada orang tua dan keluraga yang memberikan dukungan dan semangat selama proses penyelesaian artikel. Terima kasih juga kepada para dosen pembimbing yang memberikan masukan dan arahan untuk penulisan artikel yang lebih baik serta kepada seluruh pihak yang telah membantu penyelesaian penulisan artikel studi liteatur ini.

\section{DAFTAR PUSTAKA}

Adela, D., Sukarno, S., \& Indriayu, M. (2018). Integration of Environmental Education at the Adiwiyata Program Recipient School in Growing Ecoliteracy of Students. Advances in Social Science, Education and Humanities Research, 262(Ictte), 67-71. https:/ / doi.org/10.2991/ictte-18.2018.11

Badan Pusat Statistik. (2018). Laporan Indeks Perilaku Ketidakpedulian Lingkunga Hidup Indoneisa 2018.

Capra, F. (2010). Smart by Nature: Schooling for Sustainability. Journal of Sustainability Education, 122-127. http:/ / www.jsedimensions.org/wordpress/content/trial-authorchange_2010_05/print/

Cekaite, A., \& Björk-Willén, P. (2018). Enchantment in storytelling: Co-operation and participation in children's aesthetic experience. Linguistics and Education, 48(48), 5260. https:/ / doi.org/10.1016/j.linged.2018.08.005

Chodijah, S. R. (2018). The Power of Story For Children. Pustaka Mediaguru.

Dasrita, Y. (2018). Kesadaran Lingkungan Siswa. Cipta Media Edukasi.

Desfandi, M., Maryani, E., \& Disman. (2017). Building Ecoliteracy Through Adiwiyata Program (Study at Adiwiyata School in Banda Aceh). Indonesian Journal of Geography, 49(1), 51-56. https:// doi.org/10.22146/ijg.11230

Dewi, N. P. D. S., Tirtayani, L. A., \& Ganing, N. Ny. (2019). Pengaruh Metode Bercerita Berbasis Kearifan Lokal Terhadap Kemampuan Empati Anak Kelompok B. Jurnal $\begin{array}{llll}\text { Pendidikan Anak Usia Dini Undiksha, 7(1), } & \text { 78-87. }\end{array}$ https:// doi.org/10.23887/ paud.v7i1.18761

Goleman, D. (2010). Ecological Inteligence: How Knowing the Hidden Impact of What We Buy Can Change Evrything. Gramedia Pustaka Utama. 
DOI: 10.31004/obsesi.v5i1.700

Hadi, D. W. (2019, December). 434 Sekolah Raih Penghargaan Adiwiyata Tahun 2019. Kementerian Lingkungan Hidup Dan Kehutanan. https://ppid.menlhk.go.id/siaranpers/browse/2254

Haigh, C., \& Hardy, P. (2011). Tell me a story - a conceptual exploration of storytelling in healthcare education. Nurse Education Today, 31(4), 408-411. https://doi.org/10.1016/j.nedt.2010.08.001

Hamzah, A. (2020). Metode Penelitian Kepustakaan Library Research Kajian Filosofis, Aplikasi, Proses, dan Hasil Penelitian. Literasi Nusantara.

Jiwa, R. A. M., \& Esa, N. (2014). Ecological Literacy among Secondary School Students. Conference Paper, June.

Ju, E. J., \& Kim, J. G. (2011). Using soil seed banks for ecological education in primary school. Journal of Biological Education, 45(2), 93-101. https://doi.org/10.1080/00219266.2010.546010

Kalantari, F., \& Hashemian, M. (2015). A Story-Telling Approach to Teaching English to Young EFL Iranian Learners. English Language Teaching, 9(1), 221. https://doi.org/10.5539/elt.v9n1p221

Kostelnik, M. J., Soderman, A. K., \& Phipps, W. A. (2017). Kurikulum Pendidikan Anak Usia Dini Berbasis Perkembangan Anak (Developmentally Appropriate Parctices) (5th ed.). Kencana.

Masnipal. (2018). Menjadi Guru PAUD Profesional. Remaja Rosda Karya.

McBride, B. B., Brewer, C. A., Berkowitz, A. R., \& Borrie, W. T. (2013). Environmental literacy, ecological literacy, ecoliteracy: What do we mean and how did we get here? Ecosphere, 4(5). https:/ / doi.org/10.1890/ES13-00075.1

Mirza, D., Enok, M., \& Disman. (2017). Enhancing the Role of Early Childhood Education Institution in an Effort to Grow Ecoliteracy 3.1 The Importance of Eco literacy in Effort to Realize Sustainable Community. Social Science, Education and Humanities Research (ASSEHR), Volume 58 3rd International Conference on Early Childhood Education (ICECE-16) Enhancing, 58, 312-316.

Mokhtar, N. H., Halim, M. F. A., \& Kamarulzaman, S. Z. S. (2011). The effectiveness of storytelling in enhancing communicative skills. Procedia - Social and Behavioral Sciences, 18, 163-169. https://doi.org/10.1016/j.sbspro.2011.05.024

Muthukrishnan, R. (2019). Using Picture Books to Enhance Ecoliteracy of First-Grade Students. The International Journal of Early Childhood Environmental Education, 6(2), 19.

Nadiroh, N., Hasanah, U., \& Zulfa, V. (2019). Behavioral geography: An ecoliteracy perspective and critical thinking skills in men and women. Indonesian Journal of Geography, 51(2), 115-122. https:// doi.org/10.22146/ijg.36784

Nair, S. M., Yusof, N. M., \& Hong, S. C. (2014). Comparing the Effects of the Story Telling Method and the Conventional Method on the Interest, Motivation and Achievement of Chinese Primary School Pupils. Procedia - Social and Behavioral Sciences, 116, 39893995. https:// doi.org/10.1016/j.sbspro.2014.01.878

Oduolowu, E., \& Oluwakemi, E. (2014). Effect of Storytelling on Listening Skills of Primary One Pupil in Ibadan North Local Government Area of Oyo State, Nigeria. International Journey of Humanities and Social Science, 4(9), 100-107. http://www.ijhssnet.com/journals/Vol_4_No_9_July_2014/10.pdf

Pitman, S. D., \& Daniels, C. B. (2016). Quantifying ecological literacy in an adult western community: The development and application of a new assessment tool and $\begin{array}{lllll}\text { community } \quad \text { standard. } & \text { PLoS 11(3), }\end{array}$ https://doi.org/10.1371/journal.pone.0150648

Putri, S. U., \& Nikawanti, G. (2018). Pengenalan Green Behaviour melalui Ecoliteracy pada Anak Usia Dini. Cakrawala Dini: Jurnal Pendidikan Anak Usia Dini, 8(2). https://doi.org/10.17509/cd.v8i2.10538

Saribas, D., Teksoz, G., \& Ertepinar, H. (2014). The Relationship between Environmental 
Literacy and Self-efficacy Beliefs toward Environmental Education. Procedia - Social and Behavioral Sciences, 116(June 2015), 3664-3668. https:// doi.org/10.1016/j.sbspro.2014.01.820

Sarica, H. Ç., \& Usluel, Y. K. (2016). The effect of digital storytelling on visual memory and writing skills. Computers and Education, 94, 298-309. https:// doi.org/10.1016/j.compedu.2015.11.016

Slarp, M. (2014). How ecoliterate is a five year old? Investigating the effects of teaching intervention on kindergarten children's understanding of ecological concepts [The University of Sydney].

https:// ses.library.usyd.edu.au/handle/2123/13124\%0Ahttp:// prijipati.library.usyd .edu.au/handle/2123/13124

Yannis, H., \& Gillian, J. (2017). Toward More Effective Storytelling for Raising Environmental Awareness in Young Students. Journal of Advances in Education Research, 2(1), 12-18. https:/ / doi.org/10.22606/jaer.2017.21002

Yulianti, D., Rida N S, S. S., H, D., \& Diana, D. (2014). Pengembangan Karakter Peduli Lingkungan Anak Usia Dini Melalui Buku Cerita Bermuatan Sains Berwawasan Konservasi. Jurnal Penelitian Pendidikan, 31(1), 11-18. https:// doi.org/10.15294/jpp.v31i1.5681

Zed, M. (2008). Metode penelitian kepustakaan (1st ed.). Yayasan Obor indonesia. 